(c) American Dairy Science Association, 2004.

\title{
Effects of Dry Matter Intake, Addition of Buffer, and Source of Fat on Duodenal Flow and Concentration of Conjugated Linoleic Acid and Trans-11 $\mathrm{C}_{18: 1}$ in Milk*
}

\author{
X. Qiu, M. L. Eastridge, and J. L. Firkins \\ Department of Animal Sciences, The Ohio State University, Columbus 43210
}

\begin{abstract}
The primary objective of the study was to investigate the effects of DM intake, addition of buffer, and fish vs. soybean oil on duodenal flows and milk concentrations of conjugated linoleic acid (CLA) and trans-11 $\mathrm{C}_{18: 1}$. Four ruminally and duodenally cannulated multiparous cows averaging $106 \pm 17 \mathrm{~d}$ in milk at the start of the trial were used in a $4 \times 4$ Latin square design with treatments as follows: 1 ) control = diet contained $2 \%$ fish oil and fed ad libitum, 2) buffer addition (BUFF) $=$ control diet with $0.8 \%$ of $\mathrm{NaHCO}_{3}$ added, 3) low DM intake $(\mathrm{LDMI})=\mathrm{DMI}$ restricted to $80 \%$ of the control but concentration of fish oil was increased to $2.5 \%$ to provide for similar fatty acids (FA) intake, and 4) soybean oil $(\mathrm{SBO})=$ same as control except $2 \%$ soybean oil was substituted for fish oil. The diets consisted of $36.2 \%$ forage and $63.8 \%$ concentrate. Each period consisted of $18 \mathrm{~d}$, with the last $7 \mathrm{~d}$ devoted to data collection and the first $4 \mathrm{~d}$ used to determine the appropriate amount of feed to be offered to the cow on LDMI. Duodenal flows of CLA and trans- $\mathrm{C}_{18: 1}$ were lower for SBO than for diets with fish oil. Feeding buffer did not affect ruminal $\mathrm{pH}$ or duodenal flows of trans- $11 \mathrm{C}_{18: 1}$ and CLA. Restriction of DMI decreased duodenal flow of trans$11 \mathrm{C}_{18: 1}$ but did not decrease duodenal flow of CLA compared with control. In milk, CLA concentration was lower for SBO $(24.5,17.9,18.5$, and $10.1 \mathrm{mg} / \mathrm{g}$ of FA for control, BUFF, LDMI, and SBO, respectively). Cows fed fish oil had higher duodenal flow and milk concentration of n-3 polyunsaturated fatty acids than the cows fed SBO. Compared with SBO, fish oil is more effective in increasing duodenal flows of CLA and trans-11 $\mathrm{C}_{18: 1}$, and thus, concentration of CLA in milk.
\end{abstract}

(Key words: conjugated linoleic acid, restricted intake, buffer, fat source)

\footnotetext{
Received January 9, 2004.

Accepted August 18, 2004.

Corresponding author: M. L. Eastridge; e-mail: eastridge.1@ osu.edu.

*Salaries and research support provided by State and Federal funds appropriated to the Ohio Agricultural Research and Development Center, The Ohio State University.
}

Abbreviation key: $\mathbf{B H}=$ biohydrogenation, $\mathbf{B U F F}=$ buffer, CLA = conjugated linoleic acid, FA = fatty acids, LDMI = low dry matter intake, PUFA = polyunsaturated fatty acids, $\mathbf{S B O}=$ soybean oil, $\mathbf{V A}=$ vaccenic acid.

\section{INTRODUCTION}

Beef and dairy products have been suffering from a negative health image, related to the nature of their lipid fraction, which is much more saturated than nonruminant products. Consumption of fat rich in saturated fatty acids $(\mathbf{F A})$, especially lauric $\left(\mathrm{C}_{12: 0}\right)$, myristic $\left(\mathrm{C}_{14: 0}\right)$, and palmitic $\left(\mathrm{C}_{16: 0}\right)$ acids, may increase the risk of developing coronary heart disease (Berner, 1993). The discovery using animal models and tissue culture that conjugated linoleic acid (CLA), which is found in dairy products (Lin et al., 1995), possesses potential beneficial effects to human health is a positive health image of milk fat (Parodi, 1997).

According to current knowledge, milk CLA (specifically, cis- 9 trans- $11 \mathrm{C}_{18: 2}$ ) is formed ruminally by microorganisms (Kepler et al. 1966) and endogenously by enzymatic activity from vaccenic acid (trans- $11 \mathrm{C}_{18: 1}$; VA) (Griinari et al., 2000). Previously, Qiu et al. (2004) showed that CLA flows from a continuous culture system were elevated by reduced $\mathrm{pH}$ and increased dietary level of linoleic acid, and tended to be elevated by higher solid passage rate. Diets with a high level of rapidly fermented starch usually reduce ruminal $\mathrm{pH}$; feeding a buffer is an effective way to limit $\mathrm{pH}$ decline (Kalscheur et al., 1997). A higher solids passage rate from the rumen may occur when DMI increases. Studies have provided evidence that dietary fat sources affect milk CLA concentration. Kelly et al. (1998) observed that cows fed sunflower oil (rich in linoleic acid) had higher milk CLA concentration than cows fed linseed oil (rich in linolenic acid), and cows fed linseed oil had higher concentration of CLA than those fed peanut oil (rich in oleic acid). Feeding fish oil, which is rich in n-3 polyunsaturated FA (PUFA), can be an effective way to elevate CLA concentration in milk fat (Donovan et al., 2000; Jones et al., 2000). Griinari et al. (2000) estimated that about $64 \%$ of the CLA in milk might origi- 
nate via $\Delta^{9}$-desaturase; however, this number may vary with different dietary conditions.

We hypothesized that the duodenal flows of CLA and trans-11 $\mathrm{C}_{18: 1}$ in cows fed a high concentrate diet would be: 1) higher without addition of buffer to prevent a drop in ruminal $\mathrm{pH} ; 2$ ) higher with ad libitum feeding than with a restriction of DMI, which should consequently decrease solids passage rate; and 3) lower for diets containing soybean vs. fish oils. The objective of the current study was to investigate the effects of DMI, addition of buffer, and replacement of fish oil with soybean oil on duodenal flows and milk concentrations of CLA and trans- $11 \mathrm{C}_{18: 1}$ and to evaluate the contribution of endogenous synthesis of CLA to total milk CLA in dairy cows.

\section{MATERIALS AND METHODS}

\section{Animals and Diets}

Four ruminally and duodenally cannulated, primiparous Holstein cows, averaging $588 \mathrm{~kg} \mathrm{BW}$ and $106 \pm 17$ DIM at the start of the trial, were used in a $4 \times 4$ Latin square design. The treatments were as follows: 1) control = diet contained $2 \%$ fish oil and fed ad libitum; 2) buffer addition (BUFF) $=$ same as control except that $0.8 \%$ sodium bicarbonate was added as a buffer; 3 ) low DMI $($ LDMI $)=$ DMI was restricted to $80 \%$ of the control, and fish oil, CP, and mineral concentrations were increased to provide for similar amounts of intake of these components as for control; and 4) soybean oil $($ SBO $)=$ same as control diet except that $2 \%$ soybean oil was fed instead of fish oil.

The diets consisted of $13.8 \%$ alfalfa silage, $6.5 \%$ grass hay, $15.9 \%$ corn silage, and $63.8 \%$ concentrate (Table 1). Diets were prepared once daily as a TMR and fed twice daily at 0700 and $1800 \mathrm{~h}$ except for cows on LDMI. The LDMI diet was fed every $2 \mathrm{~h}$ using automatic feeders to encourage DM consumption throughout the day.

The cows were fed for $18 \mathrm{~d}$ per period; with the last $7 \mathrm{~d}$ devoted to data collection for daily DMI and milk yield (milked twice daily). The last $4 \mathrm{~d}$ of each period were devoted to collection of milk composition and digestibility data. During the first $4 \mathrm{~d}$ of each period, the cow on the LDMI treatment was fed the control diet while the other 3 cows were on their assigned diets. The DMI during the first $4 \mathrm{~d}$ was used to determine the amount of feed to be offered from d 5 to 18 for the cow fed the LDMI diet. The BW of cows was recorded weekly.

\section{Sampling Procedures}

Feed offered and refused were sampled daily during d 15 through 18 and were composited for determination
Table 1. Ingredient and chemical composition of experimental diets.

\begin{tabular}{|c|c|c|c|c|}
\hline \multirow[b]{2}{*}{ Item } & \multicolumn{4}{|c|}{ Treatment $^{1}$} \\
\hline & Control & BUFF & LDMI & SBO \\
\hline & & $-(\%$ of & M) & \\
\hline \multicolumn{5}{|l|}{ Ingredient composition } \\
\hline Alfalfa silage & 13.8 & 13.8 & 13.8 & 13.8 \\
\hline Grass hay, chopped & 6.5 & 6.5 & 6.5 & 6.5 \\
\hline Corn silage & 15.9 & 15.9 & 15.9 & 15.9 \\
\hline Dry shelled corn, ground & 17.4 & 17.0 & 16.4 & 17.4 \\
\hline Wheat, ground & 17.4 & 17.0 & 16.4 & 17.4 \\
\hline Soybean hulls & 13.8 & 13.8 & 3.7 & 13.8 \\
\hline Soybean meal, $44 \%$ CP & 8.7 & 8.7 & 18.8 & 8.7 \\
\hline Blood meal & 2.0 & 2.0 & 2.4 & 2.0 \\
\hline Fish oil & 2.0 & 2.0 & 2.5 & \\
\hline Soybean oil & $\ldots$ & $\ldots$ & $\ldots$ & 2.0 \\
\hline Sodium bicarbonate & & 0.82 & $\ldots$ & \\
\hline Dicalcium phosphate & 0.21 & 0.21 & 0.46 & 0.21 \\
\hline Feed grade limestone & 1.28 & 1.28 & 1.81 & 1.28 \\
\hline Potassium sulfate & 0.33 & 0.33 & 0.41 & 0.33 \\
\hline Magnesium oxide & 0.17 & 0.17 & 0.30 & 0.17 \\
\hline Selenium 90 premix $^{2}$ & 0.06 & 0.06 & 0.08 & 0.06 \\
\hline Trace mineralized salt & 0.43 & 0.43 & 0.54 & 0.43 \\
\hline Vitamin supplements ${ }^{3}$ & 0.07 & 0.07 & 0.09 & 0.07 \\
\hline \multicolumn{5}{|l|}{ Chemical composition } \\
\hline $\mathrm{DM}, \%$ & 60.2 & 63.0 & 60.9 & 59.8 \\
\hline $\mathrm{NDF}$ & 32.5 & 33.0 & 30.6 & 32.5 \\
\hline $\mathrm{ADF}$ & 20.5 & 19.8 & 18.3 & 19.0 \\
\hline $\mathrm{NFC}^{4}$ & 38.3 & 37.9 & 35.8 & 38.1 \\
\hline $\mathrm{CP}$ & 18.8 & 18.6 & 22.1 & 18.8 \\
\hline $\mathrm{NE}_{\mathrm{L}},{ }^{5} \mathrm{Mcal} / \mathrm{kg}$ & 1.72 & 1.72 & 1.76 & 1.72 \\
\hline Ash & 6.83 & 7.12 & 7.88 & 6.68 \\
\hline $\mathrm{P}$ & 0.40 & 0.39 & 0.49 & 0.40 \\
\hline $\mathrm{K}$ & 1.30 & 1.30 & 1.34 & 1.26 \\
\hline $\mathrm{Ca}$ & 1.04 & 1.07 & 1.26 & 1.09 \\
\hline $\mathrm{Mg}$ & 0.29 & 0.28 & 0.34 & 0.29 \\
\hline
\end{tabular}

${ }^{1} \mathrm{BUFF}=$ Buffer addition, LDMI $=$ low DM intake $(80 \%$ of ad libitum intake), and $\mathrm{SBO}=$ soybean oil.

${ }^{2}$ Contained $198 \mathrm{mg}$ of Se/kg.

${ }^{3}$ Provided $0.019 \%$ vitamin A $(30,000 \mathrm{IU} / \mathrm{g}), 0.0003 \%$ vitamin D (500,000 IU/g), and $0.068 \%$ vitamin E (44 IU/g) for treatment LDMI; and $0.015 \%$ vitamin $\mathrm{A}, 0.002 \%$ vitamin $\mathrm{D}$, and $0.053 \%$ vitamin $\mathrm{E}$ for the other 3 treatments.

${ }^{4} \mathrm{NFC}=100-\% \mathrm{NDF}-\% \mathrm{CP}-(\% \mathrm{FA} / 0.9)-\%$ ash.

${ }^{5}$ Calculated according to NRC (1989) values.

of DM, OM, N, NDF, ADF, and FA. Digestibilities of feed components were determined by the use of $\mathrm{Cr}_{2} \mathrm{O}_{3}$ mixed with soybean hulls and pelleted $\left(5 \% \mathrm{Cr}_{2} \mathrm{O}_{3}\right)$. The pellets were dosed into the rumen at each feeding (twice daily) at $100 \mathrm{~g}$ per dose from d 5 through 18. Milk samples were taken at both the a.m. and p.m. milkings on 2 consecutive days for determination of milk fat and true protein.

Ruminal fluid samples were taken on d 15 and 17 of each period at $3,6,9$, and $12 \mathrm{~h}$ after the a.m. feeding. Ruminal $\mathrm{pH}$ was measured immediately, and $50 \mathrm{~mL}$ of the fluid was collected and $3 \mathrm{~mL}$ of $6 \mathrm{~N} \mathrm{HCl}$ was added to stop fermentation. Samples taken on d 15 and 17 were composited and frozen until later analysis of VFA. Ruminal samples for harvesting of bacteria were taken at $3,6,9$, and $12 \mathrm{~h}$ after the a.m. feeding on $\mathrm{d} 15,16$, 
17 , and 18, respectively, of each period. Approximately $600 \mathrm{~mL}$ of ruminal contents were placed in a blender. Saline solution $(0.9 \%)$ was added to create a slurry, and the mixture was blended at low speed for $1 \mathrm{~min}$ to detach some of the particle-associated bacteria. The mixture of ruminal contents and saline solution was then filtered through 8 layers of cheesecloth. After filtration, $500 \mathrm{~mL}$ of fluid was collected, composited for each day of the collection period, and frozen for later centrifugation, harvesting of bacteria (Tice et al., 1993), and analyses of DM, OM, N, FA, and purines.

Duodenal samples $(280 \mathrm{~mL})$ were taken every $6 \mathrm{~h}$ during the 4-d collection period, with the starting time being advanced by $1.5 \mathrm{~h}$ each day. Samples were composited and frozen. Later, samples were thawed and 1000 -mL subsamples were taken during continued stirring. The subsamples were frozen and later analyzed for DM, OM, NDF, N, FA, Cr, and purines. Fecal samples were taken every $12 \mathrm{~h}$ during the 4-d collection period, with the start time being alternated by $3 \mathrm{~h}$ each day. Samples of feces were frozen and later analyzed for DM, OM, NDF, N, FA, and Cr.

\section{Laboratory Analyses}

To determine DMI, 200- to 250-g representative samples of feed offered and refused were dried in an oven at $55^{\circ} \mathrm{C}$ for $72 \mathrm{~h}$. Representative samples of feed offered, feed refused, duodenal contents, and feces taken during the collection period were lyophilized and ground through a 2-mm screen in a Wiley mill (Arthur A. Thomas, Philadelphia, PA). Samples of feed offered, feed refused, duodenal contents, and feces were dried at $105^{\circ} \mathrm{C}$ for determination of DM and ashed in a muffle furnace at $550^{\circ} \mathrm{C}$ for determination of $\mathrm{OM}$. Chromium concentrations of duodenal, fecal, and Cr pellet samples were determined as described by Williams et al. (1962) using a Varian SpectrAA Atomic Absorption Spectrometer 220 (Varian Australia Pty Ltd., Mulgrave, Australia). Fecal flows were calculated as the amount of $\mathrm{Cr}$ dosed divided by respective $\mathrm{Cr}$ concentrations. Purine concentration of rumen bacteria and duodenal contents were used to determine microbial flow to the duodenum (Ushida et al., 1985; Zinn and Owens, 1986). Nitrogen content of feed, digesta, and rumen bacteria were determined (Bremner and Mulvaney, 1982) using a Tecator Digestion System 20, 1015 Digestor and a Tecator Kjeltec System, 1026 Distilling Unit (Tecator AB, Hoganäs, Sweden). Analysis of fiber components was according to Goering and Van Soest (1970). To minimize the interference by fat with the fiber analysis, all feed and digesta samples were filtered with $100 \mathrm{~mL}$ of boiling ethanol before treatment in $30 \mathrm{~mL}$ of $8 M$ urea and $0.2 \mathrm{~mL}$ of $\alpha$-amylase (Sigma A-5426; Sigma Chemical Co., St.
Louis, MO). Individual minerals were analyzed by inductively coupled plasma spectrometry.

A Hewlett Packard 5890, Series II (Hewlett-Packard Company, Avondale, PA) GLC with an HP 3396A Integrator (Hewlett-Packard Company) was used for all VFA analyses. The GLC was equipped with a $1.8-\mathrm{m}$ glass column packed with GP $10 \% \mathrm{SP}-1200 / 1 \% \mathrm{H}_{3} \mathrm{PO}_{4}$ on $80 /$ 100 Chromosorb W AW (Supelco, Inc., Bellefonte, PA). The internal standard used was 2-ethylbutyric acid, and nitrogen was the carrier gas. Injector port temperature was set at $185^{\circ} \mathrm{C}$, and the detector port was set at $195^{\circ} \mathrm{C}$. The column was held at $115^{\circ} \mathrm{C}$ for $8 \mathrm{~min}$.

The FA contents of feed, digesta, and fecal samples were analyzed according to the procedure described by Sukhija and Palmquist (1988). Milk FA was analyzed according to a modification of this procedure. Milk (12 to $15 \mathrm{~mL}$ ) was centrifuged at $8000 \times g$ to form a solid milk fat layer on top of the milk, and $100 \mathrm{mg}$ of milk fat was used for analysis. Two milliliters of hexane were used as a solvent instead of benzene. Methylation occurred by heating samples for $1.5 \mathrm{~h}$ at $50^{\circ} \mathrm{C}$. After removal of the solvent layer, $1.0 \mathrm{~mL}$ of hexane was added to the original culture tube, and samples were again mixed and centrifuged, with the solvent layer being removed and composited with the first solvent layer. Approximately $0.5 \mathrm{~g}$ of anhydrous sodium sulfate was added to the composited sample, and the sample was vortexed again and let stand for $0.5 \mathrm{~h}$ before the final centrifugation.

The GLC was equipped with a $100-\mathrm{m}, 0.25-\mathrm{mm}$ i.d., SP-2560 capillary column (Supelco, Inc.) for analysis of all feed, digesta, bacteria, and milk FA. The injector and detector ports were set at $220^{\circ} \mathrm{C}$. The column was held at $175^{\circ} \mathrm{C}$ for the entire running period. To get a better reading of FA with chain length of more than 20 carbons, the samples were injected again with the GLC switched to a $30-\mathrm{m}, 0.25-\mathrm{mm}$ i.d., $10 \%$ SP-2380 fused silica capillary column (Supelco, Inc.), the injector port temperature was $230^{\circ} \mathrm{C}$, and the detector port was set at $250^{\circ} \mathrm{C}$. The column was held at $165^{\circ} \mathrm{C}$ for $13 \mathrm{~min}$ and then increased at $2.5^{\circ} \mathrm{C} / \mathrm{min}$ to $200^{\circ} \mathrm{C}$ and held for an additional $2 \mathrm{~min}$. Milk fat and true protein were determined using infrared spectroscopy (AOAC, 2000) and milk urea $\mathrm{N}$ determined by using a Skalar SAN Plus segmented flow analyzer (Peterson et al., 2004; Skalar, Inc., Norcross, GA) at the Dairy Herd Improvement Laboratory (DHI Cooperative, Inc., Columbus, $\mathrm{OH})$.

Biohydrogenation (BH) of the FA in the rumen was calculated according to the equation of Tice et al. (1994), in which the number of double bonds was considered: $\mathrm{BH}=100-\{100 \times[\mathrm{D} 18: 1+(\mathrm{D} 18: 2 \times 2)+(\mathrm{D} 18: 3 \times 3)] /$ $(\mathrm{D} 18: 0+\mathrm{D} 18: 1+\mathrm{D} 18: 2+\mathrm{D} 18: 3) /[(\mathrm{I} 18: 1+(\mathrm{I} 18: 2 \times 2)$ 
Table 2. Fatty acid composition of experimental diets.

\begin{tabular}{lcccc}
\hline & \multicolumn{4}{c}{ Treatment $^{1}$} \\
\cline { 2 - 5 } Fatty acid & Control & BUFF & LDMI & SBO \\
\cline { 2 - 5 } & \multicolumn{5}{c}{$(\mathrm{mg} / \mathrm{g}$ DM) } \\
\cline { 2 - 5 } $\mathrm{C}_{14: 0}$ & 1.62 & 1.42 & 2.04 & ND $^{2}$ \\
$\mathrm{C}_{16: 0}$ & 7.70 & 7.39 & 8.01 & 6.08 \\
$\mathrm{C}_{16: 1}$ & 1.87 & 1.77 & 2.07 & 1.59 \\
$\mathrm{C}_{18: 0}$ & 1.34 & 1.27 & 1.38 & $\mathrm{ND}$ \\
$\mathrm{C}_{18: 1} \mathrm{n}-9$ & 5.30 & 4.69 & 5.28 & 7.48 \\
$\mathrm{C}_{18: 2} \mathrm{n}-6$ & 10.3 & 10.1 & 10.83 & 15.2 \\
$\mathrm{C}_{18: 3} \mathrm{n}-3$ & 2.36 & 2.32 & 2.25 & 2.51 \\
$\mathrm{C}_{20: 5} \mathrm{n}-3$ & 1.04 & 1.12 & 1.15 & $\mathrm{ND}$ \\
$\mathrm{C}_{22: 5}$ & 0.21 & 0.23 & 0.22 & $\mathrm{ND}$ \\
$\mathrm{C}_{22: 6} \mathrm{n}-3$ & 0.87 & 1.04 & 0.96 & $\mathrm{ND}$ \\
Others $_{\text {Total fatty acids }}$ & 1.35 & 1.42 & 1.94 & 1.29 \\
\hline & 34.0 & 32.8 & 36.1 & 34.2 \\
\hline
\end{tabular}

${ }^{1} \mathrm{BUFF}=$ Buffer addition, $\mathrm{LDMI}=$ low DM intake $(80 \%$ of ad libitum intake), and SBO = soybean oil.

${ }^{2} \mathrm{ND}=$ Not detected.

+ (I18:3 × 3)]/ (I18:0 + I18:1 + I18:2 + I18:3) $\}$, where $\mathrm{D}=$ duodenal flow $(\mathrm{g} / \mathrm{d})$, and $\mathrm{I}=$ intake $(\mathrm{g} / \mathrm{d})$.

\section{Statistical Analyses}

All statistical analyses of the data except those of ruminal $\mathrm{pH}$ and VFA were performed using the GLM procedure of SAS (SAS Inst., 1999). Effects of cow, period, and dietary treatment were tested. Data for ruminal $\mathrm{pH}$ and VFA were analyzed with the MIXED model procedure of SAS (SAS Inst., 1999) with repeated measures for time of sampling. Cow was classified as a random effect. The first-order autoregressive [AR(1)] type was selected as the appropriate covariance structure for the repeated measures. Mean separation was performed using the Least Significant Difference procedure when the treatment effect was significant. Significance was declared at $P<0.05$ unless otherwise noted.

\section{RESULTS AND DISCUSSION}

\section{Animal Responses}

Control, BUFF, and SBO diets averaged $61.0 \%$ DM, $32.7 \% \mathrm{NDF}, 19.8 \% \mathrm{ADF}$, and $38.1 \% \mathrm{NFC}$ (Table 1). The concentrations of NDF, ADF, and NFC were slightly lower for LDMI because corn, wheat, and soybean hulls were replaced with fish oil and protein and mineral supplements. The CP concentrations were at $18.7 \%$ for control, BUFF, and SBO, and $22.1 \%$ for LDMI diets. The macro minerals listed in Table 1 met or exceeded NRC (1989) guidelines. Total FA contents were 3.4, 3.3, 3.6 , and $3.4 \%$ of DM for control, BUFF, LDMI, and SBO diets, respectively (Table 2), slightly lower than expected from basal ingredients plus the supplemental fat.

Cows fed LDMI had significantly lower DM and OM intakes but higher MUN than the cows fed the other 3 treatments (Table 3). However, yields of milk, $4 \%$ FCM, and milk fat and protein and milk fat and protein percentages were similar among treatments. The lack of response in milk variables probably was because $\mathrm{CP}$ and energy concentrations for LDMI were designed to be higher than the diets for other treatments so that the daily $\mathrm{CP}$ and energy intakes would be similar among cows. The MUN was higher because of the lower dietary concentration of NFC in relation to the concentration of CP and the reduced DMI may have increased ruminal ammonia concentrations and resulted in less recycling of blood urea $\mathrm{N}$ back into the gut. Formation of trans FA during microbial hydrogenation of PUFA may negatively affect the synthesis of mammary lipids (NRC, 2001). In the present study, milk fat depression was observed for all treatments because all diets contained PUFA as free oil. Milk fat percentages were 2.11, $2.18,2.26$, and 2.88 for control, BUFF, LDMI, and SBO, respectively, much lower than the average of the University's Holstein herd (3.67\%). The pattern for differences in milk fat percentage was in opposite direction to that observed for the duodenal flow of trans- $11 \mathrm{C}_{18: 1}$, indicating that fish oil appeared to more negatively affect milk fat percentage because of its higher degree of unsaturation. Jones et al. (2000) also reported low milk fat percentages when cows were fed diets containing both tallow and fish oil, with milk fat percentage averaging $2.24 \%$.

\section{Ruminal Fermentation}

Restriction of feed intake resulted in lower ruminal $\mathrm{pH}$, lower proportions of acetate and butyrate, and lower acetate-to-propionate ratio but higher proportions of propionate and valerate than the other treatments (Table 4). This may have occurred for 2 reasons. First, less soybean hulls and more soybean meal were added to LDMI, resulting in a relatively lower NDF concentration in this diet. Second, lower DMI might have led to a longer retention time and more extensive ruminal fermentation. Addition of buffer did not increase ruminal $\mathrm{pH}$ above that for control. However, buffer increased the proportion of acetate and decreased the proportion of propionate compared with control; thus, the acetate-to-propionate ratio was increased. Feeding SBO instead of fish oil resulted in the highest ruminal $\mathrm{pH}$, proportion of acetate, and acetate-to-propionate ratio but the lowest concentration of total VFA and proportion of propionate. In most studies involving the feeding of fat, in particular fish oil, a significant 
QUI ET AL.

Table 3. Effect of buffer addition, DMI, and fat source on performance of lactating cows.

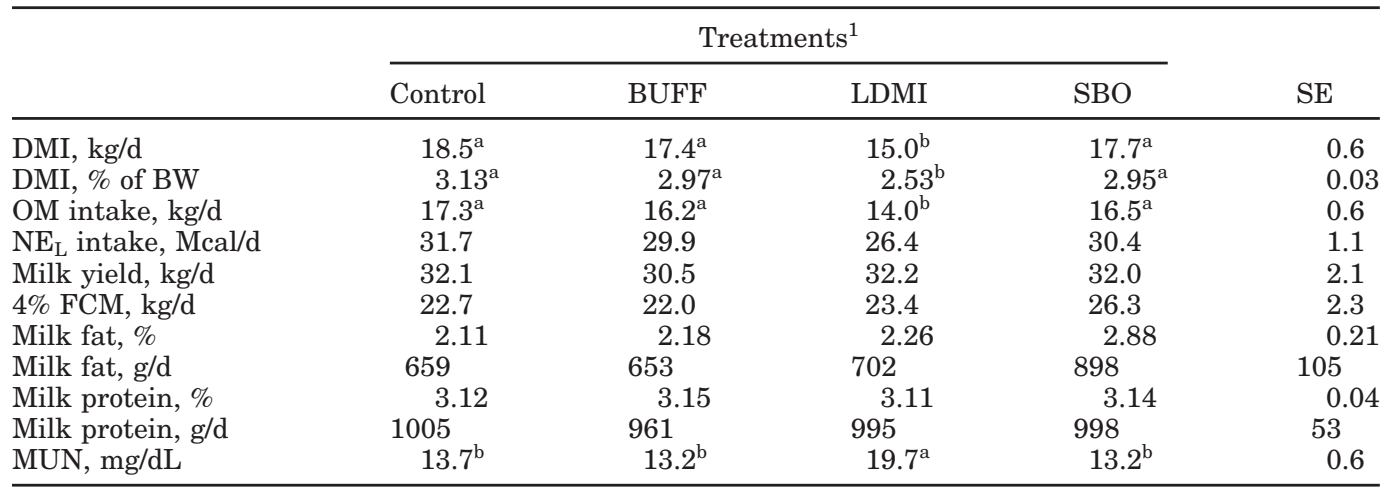

\footnotetext{
${ }^{\mathrm{ab}}$ Means in the same row with different letters differ $(P<0.05)$.

${ }^{1} \mathrm{BUFF}=0.8 \%$ Buffer addition, LDMI $=$ low DM intake (80\% of ad libitum intake), and $\mathrm{SBO}=2 \%$ soybean
} oil.

increase in the proportion of propionate and a decrease in acetate were observed (Nicholson and Sutton, 1971; Doreau and Chilliard, 1997). These results are thought to be due to a modification of the ruminal microbial ecosystem, as occurs with 18-carbon PUFA. A decrease in the numbers of cellulolytic and methanogenic bacteria is observed with the feeding of most fat sources (Demeyer and van Nevel, 1995; Doreau and Ferlay, 1995). Thus, the increase in propionate may be due to a decreased opportunity for methane as an electron sink. In the present study, all diets were supplemented with fat, yet significant differences were found in acetate-to-propionate ratio, with the ranking being $\mathrm{SBO}>$ BUFF $>$ control $>$ LDMI. Soybean oil may affect ruminal fermentation to a lesser extent than fish oil.

\section{Duodenal FA Flow}

Generally, control and BUFF were similar in duodenal flows of total FA and all individual FA (Table 5). The LDMI diet decreased duodenal flows of $\mathrm{C}_{16: 1}$ and trans-11 $\mathrm{C}_{18: 1}$ compared with control. Feeding SBO in- stead of fish oil increased duodenal flow of stearic acid $\left(\mathrm{C}_{18: 0}\right)$ but decreased flows of $\mathrm{C}_{14: 0}, \mathrm{C}_{16: 0}, \mathrm{C}_{16: 1}$, and trans$11 \mathrm{C}_{18: 1}$. Feeding buffer and restricting feed intake resulted in similar CLA flow compared with control, but SBO resulted in the lowest duodenal flow of CLA. The extent of $\mathrm{BH}$ of 18-carbon FA was highest for SBO because of the amount of linoleic acid that was available for $\mathrm{BH}$ to stearic acid.

\section{Milk FA Composition}

There were no treatment effects $(P>0.10)$ on milk concentrations of FA with chain length of 12 or shorter (Table 6), indicating a similar extent of de novo syntheses of these FA among treatments. Feeding SBO increased $\mathrm{C}_{18: 0}$, cis- $\mathrm{C}_{18: 1}$, and $\mathrm{C}_{18: 2}$ and tended $(P<0.10)$ to decrease $\mathrm{C}_{14: 0}, \mathrm{C}_{16: 0}, \mathrm{C}_{16: 1}$, and trans- $11 \mathrm{C}_{18: 1}$ concentrations in milk fat more than feeding fish oil, but there were no differences in these FA among the 3 treatments with fish oil. The CLA concentrations in milk fat were lower for SBO.

Table 4. Effect of buffer addition, DMI, and fat source on ruminal $\mathrm{pH}$ and VFA production.

\begin{tabular}{lccccc}
\hline & \multicolumn{4}{c}{ Treatment $^{1}$} & SE \\
\cline { 2 - 5 } & Control & BUFF & LDMI & SBO & 0.04 \\
\hline $\mathrm{pH}$ & $6.17^{\mathrm{b}}$ & $6.22^{\mathrm{b}}$ & $5.93^{\mathrm{c}}$ & $6.41^{\mathrm{a}}$ & $113^{\mathrm{b}}$ \\
Total VFA, mM & $126^{\mathrm{a}}$ & $128^{\mathrm{a}}$ & $135^{\mathrm{a}}$ & $66.8^{\mathrm{a}}$ & 0.4 \\
Acetate, mol/100 mol & $60.1^{\mathrm{c}}$ & $64.8^{\mathrm{b}}$ & $57.9^{\mathrm{d}}$ & $16.1^{\mathrm{c}}$ & 0.5 \\
Propionate, mol/100 mol & $24.1^{\mathrm{b}}$ & $17.1^{\mathrm{c}}$ & $27.6^{\mathrm{a}}$ & $12.7^{\mathrm{b}}$ & 0.3 \\
Butyrate, $\mathrm{mol} / 100 \mathrm{~mol}$ & $11.7^{\mathrm{c}}$ & $13.9^{\mathrm{a}}$ & $10.0^{\mathrm{d}}$ & $1.18^{\mathrm{a}}$ & 0.03 \\
Isobutyrate, mol/100 mol & $0.95^{\mathrm{b}}$ & $1.17^{\mathrm{a}}$ & $0.91^{\mathrm{b}}$ & $1.36^{\mathrm{b}}$ & 0.04 \\
Valerate, mol/100 mol & $1.56^{\mathrm{a}}$ & $1.33^{\mathrm{b}}$ & $1.81^{\mathrm{c}}$ & $1.76^{\mathrm{ab}}$ & 0.05 \\
Isovalerate, mol/100 mol & $1.62^{\mathrm{c}}$ & $1.71^{\mathrm{bc}}$ & $1.86^{\mathrm{a}}$ & $4.16^{\mathrm{a}}$ & 0.07 \\
Acetate:propionate & $2.50^{\mathrm{c}}$ & $3.84^{\mathrm{b}}$ & $2.14^{\mathrm{d}}$ & &
\end{tabular}

${ }^{\mathrm{abc}}$ Means in the same row with different letters differ $(P<0.05)$.

${ }^{1} \mathrm{BUFF}=0.8 \%$ Buffer addition, LDMI $=$ low DMI ( $80 \%$ of ad libitum intake), and SBO $=2 \%$ soybean oil. 
Table 5. Effect of buffer addition, DMI, and fat source on duodenal flow of fatty acids.

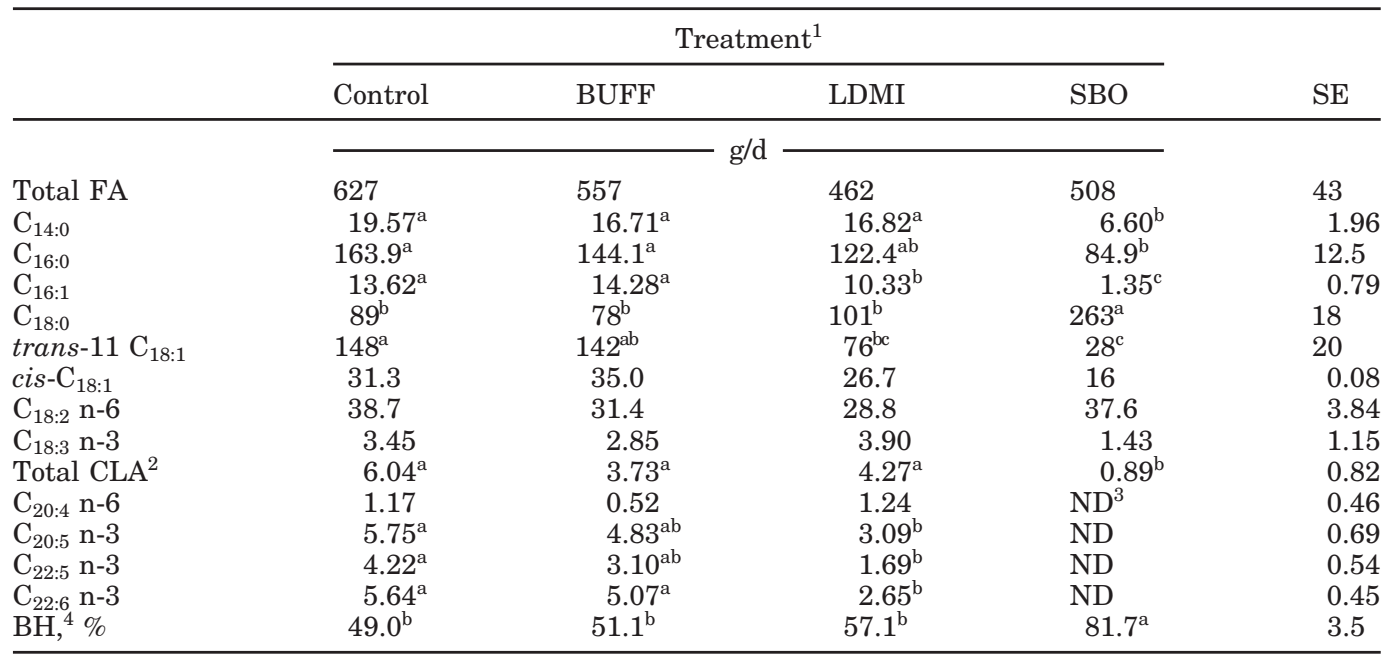

${ }^{a b c}$ Means in the same row with different letters differ $(P<0.05)$.

${ }^{1} \mathrm{BUFF}=0.8 \%$ Buffer addition, LDMI $=$ low DMI (80\% of ad libitum intake), and $\mathrm{SBO}=2 \%$ soybean oil. ${ }^{2} \mathrm{CLA}=$ Conjugated linoleic acid.

${ }^{3} \mathrm{ND}=$ Not detectable.

${ }^{4} \mathrm{BH}=$ Biohydrogenation, calculated according to one of the equations of Tice et al. (1994) that includes the number of double bonds in the calculation.

Table 6. Effect of buffer addition, DMI, and fat source on fatty acid (FA) composition in milk.

\begin{tabular}{|c|c|c|c|c|c|}
\hline & \multicolumn{4}{|c|}{ Treatment $^{1}$} & \multirow[b]{2}{*}{$\mathrm{SE}$} \\
\hline & Control & BUFF & LDMI & $\mathrm{SBO}$ & \\
\hline & \multicolumn{4}{|c|}{$\longrightarrow \mathrm{mg} / \mathrm{g}$ of FA $\longrightarrow$} & \\
\hline $\mathrm{C}_{4: 0}$ & 5.61 & 5.18 & 6.16 & 6.38 & 0.76 \\
\hline $\mathrm{C}_{6: 0}$ & 10.4 & 8.7 & 14.0 & 12.8 & 1.7 \\
\hline $\mathrm{C}_{8: 0}$ & 11.5 & 10.7 & 13.4 & 12.1 & 1.3 \\
\hline $\mathrm{C}_{10: 0}$ & 28.7 & 26.3 & 32.6 & 29.0 & 3.0 \\
\hline $\mathrm{C}_{12: 0}$ & 37.8 & 36.6 & 40.4 & 35.9 & 3.2 \\
\hline $\mathrm{C}_{14: 0}$ & 129 & 124 & 129 & 115 & 4 \\
\hline $\mathrm{C}_{16: 0}$ & 354 & 326 & 335 & 290 & 14 \\
\hline $\mathrm{C}_{16: 1}$ & 41.9 & 44.6 & 33.8 & 19.6 & 6.1 \\
\hline $\mathrm{C}_{18: 0}$ & $38.6^{\mathrm{b}}$ & $43.4^{\mathrm{b}}$ & $53.4^{\mathrm{b}}$ & $107.0^{\mathrm{a}}$ & 12.2 \\
\hline trans- $11 \mathrm{C}_{18: 1}$ & $95.6^{\mathrm{a}}$ & $99.5^{\mathrm{a}}$ & $70.7^{\mathrm{ab}}$ & $35.8^{\mathrm{b}}$ & 15.5 \\
\hline cis- $\mathrm{C}_{18: 1}$ & $136^{\mathrm{b}}$ & $152^{\mathrm{b}}$ & $163^{\mathrm{b}}$ & $242^{\mathrm{a}}$ & 16.3 \\
\hline$C_{18: 2} n-6$ & $28.8^{\mathrm{b}}$ & $30.6^{\mathrm{b}}$ & $27.8^{\mathrm{b}}$ & $39.6^{\mathrm{a}}$ & 2.4 \\
\hline $\mathrm{C}_{18: 3} \mathrm{n}-3$ & 3.72 & 3.91 & 3.64 & 4.36 & 0.42 \\
\hline Total CLA ${ }^{2}$ & $24.5^{\mathrm{a}}$ & $17.9^{\mathrm{a}}$ & $18.5^{\mathrm{a}}$ & $10.1^{\mathrm{b}}$ & 2.4 \\
\hline $\mathrm{C}_{20: 4} \mathrm{n}-6$ & 2.38 & 3.40 & 1.43 & 0.38 & 0.72 \\
\hline $\mathrm{C}_{20: 5} \mathrm{n}-3$ & $2.25^{\mathrm{a}}$ & $3.58^{\mathrm{a}}$ & $2.33^{\mathrm{a}}$ & $0.53^{\mathrm{b}}$ & 0.51 \\
\hline $\mathrm{C}_{22: 5} \mathrm{n}-3$ & 2.15 & 1.88 & 3.40 & 1.53 & 0.74 \\
\hline $\mathrm{C}_{22: 6} \mathrm{n}-3$ & $1.68^{\mathrm{a}}$ & $0.63^{\mathrm{a}}$ & $1.13^{\mathrm{a}}$ & $0.08^{\mathrm{b}}$ & 0.08 \\
\hline CLA production, ${ }^{3} \mathrm{~g} / \mathrm{d}$ & 14.6 & 10.0 & 10.8 & 9.1 & 2.0 \\
\hline Endogenous CLA, ${ }^{4} \%$ of CLA production & $68.5^{\mathrm{b}}$ & $67.6^{\mathrm{b}}$ & $65.8^{\mathrm{b}}$ & $86.4^{\mathrm{a}}$ & 4.7 \\
\hline trans-11 $\mathrm{C}_{18: 1}$ desaturation, ${ }^{5} \%$ & $14.2^{\mathrm{b}}$ & $16.1^{\mathrm{ab}}$ & $17.5^{\mathrm{ab}}$ & $19.8^{\mathrm{a}}$ & 1.8 \\
\hline
\end{tabular}

${ }^{\mathrm{ab}} \mathrm{Means}$ in the same row with different letters differ $(P<0.05)$.

${ }^{1} \mathrm{BUFF}=0.8 \%$ Buffer addition, LDMI $=$ low DMI (80\% of ad libitum intake), and $\mathrm{SBO}=2 \%$ soybean oil. ${ }^{2} \mathrm{CLA}=$ Conjugated linoleic acid.

${ }^{3}$ Calculated by: CLA concentration in milk fat $\times($ milk fat yield $\times 0.9)$, assuming that fatty acids account for $90 \%$ of milk fat.

${ }^{4}$ Calculated by: $\{[($ Milk CLA, g) $-($ Duodenal CLA, g) $] /($ Milk CLA g) $) \times 100$.

${ }^{5}$ Calculated by: $\{[($ Milk CLA, g) - (Duodenal CLA, g) ] [ [(Milk CLA, g) - (Duodenal CLA, g) + (Milk trans$\left.\left.\left.11 \mathrm{C}_{18: 1}, \mathrm{~g}\right)\right]\right\} \times 100$. 
Feeding buffer did not affect duodenal flow of CLA but tended $(P<0.10)$ to decrease CLA concentration in milk fat. Chouinard et al. (1998) found that feeding different buffers had no effect on CLA concentration in milk. In the present study, the CLA concentration in milk fat tended $(P<0.10)$ to be lower for the cows on LDMI than on control. Jiang et al. (1996) studied the effects of different diets (high vs. low concentrate) and different feeding regimens (ad libitum vs. restricted intakes) on the variation of CLA in milk. Cows fed the high concentrate diet at restricted intake had the highest concentration of CLA in milk $(11.28 \mathrm{mg} / \mathrm{g}$ of fat). Meal pattern may explain some of the difference between the 2 studies on response of milk CLA concentration to feed restriction of a high concentrate diet.

Generally, feeding fish oil increases VA, CLA, and n3 FA in milk (Donovan et al., 2000; Jones et al., 2000), and our data were consistent with these findings. Because CLA concentration is usually less than $10 \mathrm{mg} / \mathrm{g}$ of fat and very long chain n-3 PUFA are barely detectable in milk under normal feeding conditions (Lin et al., 1995), it is clear that feeding fish oil is an effective way to increase concentrations of CLA and n-3 PUFA in milk fat. Little information is available on the direct comparison of fish oil with soybean oil on duodenal flow of CLA and concentration of CLA in milk. A study by Offer et al. (1999) revealed that fish oil was more effective than linseed oil at increasing CLA in milk. General information drawn from different studies (Dhiman et al., 2000; Donovan et al., 2000) indicates that fish oil might be more effective than SBO in promoting CLA concentration in milk. The present study supports the same conclusion.

Griinari et al. (2000) demonstrated that CLA could be endogenously synthesized from VA in the mammary gland by the activity of $\Delta^{9}$-desaturase. They also estimated that about $64 \%$ of the CLA in milk might have originated via $\Delta^{9}$-desaturase. Corl et al. (2000), using a similar strategy, revealed that a maximum of $78 \%$ of milk CLA was derived from endogenous synthesis. Morales et al. (2000) observed that apparent conversion of VA to CLA by the mammary gland of dairy cows is influenced by the source of dietary fat, with the conversion in animals fed tallow being higher than those fed roasted whole soybeans.

Using the methods shown in Table 6, the endogenous contribution of CLA for SBO (86.4\%) was nearly $20 \%$ higher than for the other 3 treatments (averaging $67.3 \%$ ). Using these calculations, the duodenal flow of CLA was assumed to be completely absorbed and taken up by the mammary gland, which is unlikely; therefore, the results obtained in the present study should be viewed as the minimal levels under the specific feeding conditions. Corl et al. (2000) and Griinari et al. (2000) estimated the contribution of endogenous CLA synthesis by using sterculic acid to inhibit $\Delta^{9}$-desaturase activity, and the extent of inhibition was calculated according to the reduction of $\mathrm{C}_{14: 1}$ secretion in the milk. However, because the kinetics for sterculic acid inhibition of $\Delta^{9}$-desaturase have not been compared for different substrates, it is possible that the extent of inhibition was different for VA than for $\mathrm{C}_{14: 0}$.

Griinari et al. (1999) showed a strong relationship between CLA and VA concentrations of milk fat: CLA, $\%=-0.05+0.54(\mathrm{VA}, \%),\left(\mathrm{r}^{2}=0.87\right)$, suggesting that about $35 \%$ of VA taken up by the mammary tissue was desaturated to CLA. Jahreis et al. (1999) reported a combined relationship for milk fat of ruminants and nonruminants of CLA, \% $=0.141+0.318(\mathrm{VA}, \%),\left(\mathrm{r}^{2}=\right.$ 0.90 ), indicating a desaturation of about $24 \%$ of the VA taken up by mammary gland. By taking the same approach, the relationship between CLA and VA concentrations of milk fat was obtained as follows: CLA, $\%=0.575+0.119(\mathrm{VA}, \%),\left(\mathrm{r}^{2}=0.42, P=0.007\right)$, indicating a desaturation of about $10.6 \%$ of the VA taken up by mammary gland. These estimations assume that the increase in milk CLA is only from desaturation of VA, whereas the uptake of CLA may also increase as the uptake of VA increases. In the present study, a different approach was taken to estimate the extent of desaturation of trans- $11 \mathrm{C}_{18: 1}$ : trans-11 $\mathrm{C}_{18: 1}$ desaturation, $\%=$ \{[(milk CLA, g) - (duodenal CLA, g)]/ [(milk CLA g) (duodenal CLA, g) + (milk trans-11 $\left.\left.\left.\mathrm{C}_{18: 1}, \mathrm{~g}\right)\right]\right\} \times 100$. The desaturation of trans-11 $\mathrm{C}_{18: 1}$ was higher for cows fed SBO (19.8\%) than those fed control (14.4\%). There was no difference among cows fed the 3 diets with fish oil. The estimated desaturation of trans- $11 \mathrm{C}_{18: 1}$ in the present study is comparatively low. This calculation should represent the minimal levels under the corresponding feeding conditions because the equation assumes that the duodenal flow of CLA was completely absorbed and taken up by mammary gland. Another reason for the low numbers is that different isomers of trans $-\mathrm{C}_{18: 1}$ were not successfully separated in this study. Evidence exists that the trans-10 isomer is desaturated only to a limited extent (Mahfouz et al., 1980). Nevertheless, the present study suggests that the desaturation of VA into CLA may be lower for dairy cows than for nonruminant species (e.g., rat). However, because ruminant animals produce more VA than nonruminants, the absolute amount of VA desaturated in ruminant animals is high.

Studies in rats (Engler et al., 2000) and pigs (Kouba and Mourot, 1998) indicate that diets with fish oil and high concentration of linoleic oil decrease $\Delta^{9}$-desaturase activity. The present study suggests that fish oil may be more inhibitory than soybean oil on $\Delta^{9}$-desaturase activity in ruminant animals. 
Table 7. Effect of buffer addition, DMI, and fat source on nutrient digestibility.

\begin{tabular}{|c|c|c|c|c|c|}
\hline & \multicolumn{4}{|c|}{ Treatment $^{1}$} & \multirow[b]{2}{*}{$\mathrm{SE}$} \\
\hline & Control & BUFF & LDMI & SBO & \\
\hline \multicolumn{6}{|l|}{$\mathrm{OM}$} \\
\hline Intake, $\mathrm{kg} / \mathrm{d}$ & 17.4 & 15.7 & 14.5 & 16.5 & 0.6 \\
\hline Apparent stomach digestibility, \% & $47.9^{\mathrm{b}}$ & $47.2^{\mathrm{b}}$ & $51.0^{\mathrm{b}}$ & $59.2^{\mathrm{a}}$ & 1.9 \\
\hline True stomach digestibility, $\%$ & $61.5^{\mathrm{b}}$ & $60.2^{\mathrm{b}}$ & $63.1^{\mathrm{b}}$ & $69.5^{\mathrm{a}}$ & 1.8 \\
\hline Apparent intestinal digestibility, $\%$ of intake & $27.5^{\mathrm{a}}$ & $23.0^{\mathrm{a}}$ & $21.3^{\mathrm{ab}}$ & $14.5^{\mathrm{b}}$ & 2.3 \\
\hline Total tract digestibility, $\%$ & 75.3 & 70.1 & 72.3 & 73.6 & 2.7 \\
\hline \multicolumn{6}{|l|}{ NDF } \\
\hline Intake, kg/d & 6.04 & 5.58 & 4.83 & 5.50 & 0.29 \\
\hline Stomach digestibility, \% & 39.2 & 42.9 & 44.2 & 43.5 & 3.8 \\
\hline Intestinal digestibility, $\%$ of intake & 18.7 & 8.23 & 7.44 & 7.61 & 2.59 \\
\hline Total tract digestibility, $\%$ & 57.8 & 51.1 & 51.6 & 51.1 & 4.4 \\
\hline \multicolumn{6}{|l|}{$\mathrm{CP}$} \\
\hline Intake, kg/d & 3.88 & 3.47 & 3.76 & 3.51 & 0.16 \\
\hline Duodenal flow, kg/d & $3.40^{\mathrm{a}}$ & $2.92^{\mathrm{b}}$ & $2.78^{\mathrm{bc}}$ & $2.51^{\mathrm{c}}$ & 0.12 \\
\hline Duodenal microbial N flow, g/d & $250^{\mathrm{a}}$ & $204^{\mathrm{ab}}$ & $175^{\mathrm{b}}$ & $172^{\mathrm{b}}$ & 15 \\
\hline True stomach digestibility, $\%$ & 51.3 & 52.0 & 55.2 & 57.8 & 3.1 \\
\hline $\begin{array}{l}\text { Efficiency of microbial protein synthesis, } \\
\text { g N/kg of OM truly digested }\end{array}$ & $22.9^{\mathrm{a}}$ & $21.7^{\mathrm{a}}$ & $19.4^{\mathrm{ab}}$ & $15.8^{\mathrm{b}}$ & 1.1 \\
\hline Apparent intestinal digestibility, $\%$ of intake & $64.1^{\mathrm{a}}$ & $55.6^{\mathrm{ab}}$ & $48.2^{\mathrm{b}}$ & $44.8^{\mathrm{b}}$ & 3.6 \\
\hline Total tract digestibility, $\%$ & 76.0 & 71.1 & 74.1 & 71.9 & 3.5 \\
\hline \multicolumn{6}{|l|}{ Fatty acids } \\
\hline Intake, $\mathrm{g} / \mathrm{d}$ & 626 & 537 & 486 & 573 & 32 \\
\hline Duodenal flow, g/d & 602 & 549 & 461 & 490 & 39 \\
\hline Duodenal microbial flow, g/d & 339 & 277 & 204 & 312 & 35 \\
\hline Apparent stomach digestibility, \% & 4.8 & -1.6 & 5.3 & 12.0 & 5.2 \\
\hline Apparent intestinal digestibility, \% of intake & $88.4^{\mathrm{a}}$ & $93.0^{\mathrm{a}}$ & $83.1^{\mathrm{a}}$ & $69.2^{\mathrm{b}}$ & 4.5 \\
\hline Total tract digestibility, $\%$ & $93.1^{\mathrm{a}}$ & $91.5^{\mathrm{a}}$ & $88.4^{\mathrm{a}}$ & $81.2^{\mathrm{b}}$ & 1.8 \\
\hline
\end{tabular}

${ }^{\mathrm{abc}}$ Means in the same row with different letters differ $(P<0.05)$.

${ }^{1} \mathrm{BUFF}=0.8 \%$ Buffer addition, LDMI = low DMI (80\% of ad libitum intake), and SBO = 2\% soybean oil.

\section{Nutrient Digestibilities}

Feeding SBO resulted in the highest apparent and true stomach digestibilities of OM compared with the other treatments (Table 7). This may have happened because SBO usually has less adverse effect on bacteria than fish oil, which should have resulted in a change in bacterial population. Intestinal digestibilities of OM and $\mathrm{CP}$ were lower for SBO than control, but total tract digestibilities for $\mathrm{OM}$ and $\mathrm{CP}$ were similar among treatments. Site and extent of NDF digestion were similar among treatments, and stomach and total tract digestibilities of NDF for SBO (free oil) were similar to those observed for whole raw and roasted soybeans (Tice et al., 1993). Efficiency of microbial protein synthesis (grams of $\mathrm{N}$ per kilogram of OM truly digested) was lower for SBO and lower than observed when raw and roasted soybeans were fed (Tice et al., 1993). Total tract and intestinal digestibilities of FA were lower for SBO than other treatments but higher than for those observed when soybeans were fed (Tice et al., 1993). The total tract digestibilities of FA were similar among the diets containing fish oil and were slightly higher than those observed by Doreau and Chilliard (1997). Kalscheur et al. (1997) found low dietary forage concentration ( 25 vs. $60 \%$ ) to reduce ruminal digestibility of
OM, but buffer addition tended to increase OM digestibility. Ruminal $\mathrm{pH}$ was improved from 5.83 to 6.02 by buffer addition. In the present study, all diets contained $36 \%$ forage, and ruminal $\mathrm{pH}$ was 6.17 for control and 6.22 for BUFF. This could explain not only the similarity of nutrient digestibilities but also the similarity of the duodenal content and flows of FA between these 2 treatments.

\section{CONCLUSIONS}

In the present study, feeding $0.8 \%$ sodium bicarbonate to lactating dairy cows did not increase ruminal $\mathrm{pH}$ or decrease duodenal flows of trans-11 $\mathrm{C}_{18: 1}$ and CLA. Restriction of feed intake decreased duodenal flow of trans-11 $\mathrm{C}_{18: 1}$ but not that of CLA compared with control, possibly due to a combined effect of longer retention time in the rumen, which is not in favor of formation of CLA and trans-11 $\mathrm{C}_{18: 1}$, and a reduced $\mathrm{pH}$, which is in favor of the production of CLA and trans- $11 \mathrm{C}_{18: 1}$ in the rumen. The CLA concentrations in milk fat were $24.5,17.9,18.5$, and $10.1 \mathrm{mg} / \mathrm{g}$ of FA for control, BUFF, LDMI, and SBO diets, respectively. Endogenous synthesis of CLA by $\Delta^{9}$-desaturase activity likely accounts for most of the CLA secreted in milk, and the contribution of endogenous CLA can vary with source of dietary 
fat. Compared with soybean oil, fish oil may have more effects on ruminal fermentation, and thus, be more effective in increasing duodenal flows of CLA and trans$11 \mathrm{C}_{18: 1}$ and milk concentration of CLA.

\section{REFERENCES}

Association of Official Analytical Chemists. 2000. Official Methods of Analysis. 17th ed. AOAC Int., Gaithersburg, MD.

Berner, L. A. 1993. Defining the role of milkfat in balanced diets. Adv. Food Nutr. Res. 37:131-257.

Bremner, J. M., and C. S. Mulvaney. 1982. Pages 595-624 in Methods of soil analysis, Part 2. Chemical and microbiological properties. A. L. Page, R. H. Miller, and D. R. Keeney, ed. Am. Soc. Agron.Soil Sci. Soc. Am., Madison, WI.

Chouinard, P. Y., L. Corneau, M. L. Kelly, J. M. Griinari, and D. E. Bauman. 1998. Effect of dietary manipulation on milk conjugated linoleic acid concentrations. J. Dairy Sci. 81(Suppl.1):233. (Abstr.)

Corl, B. A., L. H. Baumgard, D. A. Dwyer, J. M. Griinari, B. S. Phillips, and D. E. Bauman. 2000. The role of $\Delta 9$-desaturase in the production of cis-9, trans-11 CLA and other $\Delta 9$ desaturated fatty acids in milk fat. J. Dairy Sci. 83(Suppl. 1):164. (Abstr.)

Demeyer, D. I., and C. J. Van Nevel. 1995. Transformations and effects of lipids in the rumen: Three decades of research at Gent University. Arch. Anim. Nutr. 48:119-134.

Dhiman, T. R., L. D. Satter, M. W. Pariza, M. P. Galli, K. Albright, and M. X. Tolosa. 2000. Conjugated linoleic acid (CLA) content of milk from cows offered diets rich in linoleic and linolenic acid. J. Dairy Sci. 83:1016-1027.

Donovan, D. C., D. J. Schingoethe, R. J. Baer, J. Ryali, A. R. Hippen, and S. T. Franklin. 2000. Influence of dietary fish oil on the concentration of conjugated linoleic acid and other fatty acids in milk fat from lactating dairy cows. J. Dairy Sci. 83:2620-2628.

Doreau, M., and Y. Chilliard. 1997. Effects of ruminal or postruminal fish oil supplementation on intake and digestion in dairy cows. Reprod. Nutr. Dev. 37:113-124.

Doreau, M., and A. Ferlay. 1995. Effect of dietary lipid on nitrogen metabolism in the rumen: A review. Livest. Prod. Sci. 43:97-110.

Engler, M. M., S. H. Bellenger-Germain, M. B. Engler, M. M. Narce, and J. G. Poisson. 2000. Dietary docosahexaenoic acid affects stearic acid desaturation in spontaneously hypertensive rats. Lipids 35:1011-1015.

Goering, H. K., and P. J. Van Soest. 1970. Forage Fiber Analysis (Apparatus, Reagents, Procedures, and some Applications). Agric. Handb. No. 379. ARS-USDA, Washington, DC.

Griinari, J. M., B. A. Corl, S. H. Lacy, P. Y. Chouinard, K. V. V. Nurmela, and D. E. Bauman. 2000. Conjugated linoleic acid is synthesized endogenously in lactating dairy cows by $\Delta 9$-desaturase. J. Nutr. 130:2285-2291.

Griinari, J. M., A. T. Tesfa, M. Tuori, and M. Holma. 1999. Effect of feeding graded levels of partially hydrogenated soybean oil fatty acids to lactating dairy cows on concentrations of conjugated linoleic acid (CLA) in milk fat. J. Dairy Sci. 82(Suppl.1):84. (Abstr.)

Jahreis, G., J. Fritsche, P. Möckel, F. Schöne, U. Möller, and H. Steinhart. 1999. The potential anticarcinogenic conjugated linoleic acid, cis-9, trans-11 $\mathrm{C}_{18: 2}$, in milk of different species: Cow, goat, ewe, sow, mare, women. Nutr. Res. 19:1541-1549.

Jiang, J., L. Bjoerck, R. Fonden, and M. Emanuelson. 1996. Occurrence of conjugated cis-9, trans-11-octadecadienoic acid in bovine milk: Effects of feed and dietary regimen. J. Dairy Sci. 79:438445.

Jones, D. F., W. P. Weiss, and D. L. Palmquist. 2000. Short Communication: Influence of dietary tallow and fish oil on milk fat composition. J. Dairy Sci. 83:2024-2026.
Kalscheur, K. F., B. B. Teter, L. S. Piperova, and R. A. Erdman. 1997. Effect of dietary forage concentration and buffer addition on duodenal flow of trans-C18:1 fatty acids and milk fat production in dairy cows. J. Dairy Sci. 80:2104-2114.

Kelly, M. L., J. R. Berry, D. A. Dwyer, J. M. Griinari, P. Y. Chouinard, M. E. Van Amburgh, and D. E. Bauman. 1998. Dietary fatty acid sources affect conjugated linoleic acid concentration in milk from lactating dairy cows. J. Nutr. 128:881-885.

Kepler, C. R., K. P. Hirons, J. J. McNeill, and S. B. Tove. 1966. Intermediates and products of the biohydrogenation of linoleic acid by Butyrivibrio fibrisolvens. J. Biol. Chem. 241:1350-1354.

Kouba, M., and J. Mourot. 1998. Effect of a high linoleic acid diet on delta-9-desaturase activity, lipogenesis and lipid composition of pig subcutaneous adipose tissue. Reprod. Nutr. Dev. 38:31-37.

Lin, H., T. D. Boylston, M. J. Chang, L. O. Luedeke, and T. D. Shultz. 1995. Survey of the conjugated linoleic content of dairy products. J. Dairy Sci. 78:2358-2365.

Mahfouz, M. M., A. J. Valicenti, and R. T. Holman. 1980. Desaturation of isomeric trans-octadecadienoic acids by rat liver microsomes. Biochem. Biophys. Acta 618:1-12.

Morales, M. S., D. L. Palmquist, and W. P. Weiss. 2000. Effects of fat source and copper on unsaturation of blood and milk triacylglycerol fatty acids in Holstein and Jersey cows. J. Dairy Sci. 83:2105-2111.

National Research Council. 1989. Nutrient requirements of dairy cattle. 6th rev. ed. Natl. Acad. Sci., Washington, DC.

National Research Council. 2001. Nutrient requirements of dairy cattle. 7th rev. ed. Natl. Acad. Sci., Washington, DC.

Nicholson, J. W. G., and J. D. Sutton. 1971. Some effects of unsaturated oils given to dairy cows with rations of different roughage content. J. Dairy Res. 38:363-372.

Offer, N. W., M. Marsden, J. Dixon, B. K. Speake, and F. E. Thacker. 1999. Effect of dietary fat supplements on levels of n-3 polyunsaturated fatty acids, trans acids and conjugated linoleic acid in bovine milk. Anim. Sci. 69:613-625.

Parodi, P. W. 1997. Cow's milk fat components as potential anticarcinogenic agents. J. Nutr. 127:1055-1060.

Peterson, A. B., K. R. French, E. Russek-Cohen, and R. A. Kohn. 2004. Comparison of analytical methods and the influence of milk components on milk urea nitrogen recovery. J. Dairy Sci. 87:1747-1750.

Qiu, X., M. L. Eastridge, K. E. Griswold, and J. L. Firkins. 2004. Effects of substrate, passage rate, and $\mathrm{pH}$ in continuous culture on flows of conjugated linoleic acid and trans $\mathrm{C}_{18: 1}$. J. Dairy Sci. 87:3473-3479.

SAS Institute, Inc. 1999. What's new in SAS software for Version 7 and the version 8 developer's release. SAS Inst., Inc., Cary, NC.

Sukhija, P. S., and D. L. Palmquist. 1988. Rapid method for determination of total fatty acid content and composition of feedstuffs and feces. J. Agric. Food Chem. 36:1202-1206.

Tice, E. M., M. L. Eastridge, and J. L. Firkins. 1993. Raw soybeans and roasted soybeans of different particle sizes. 1. Digestibility and utilization by lactating cows. J. Dairy Sci. 76:224-235.

Tice, E. M., M. L. Eastridge, and J. L. Firkins. 1994. Raw soybeans and roasted soybeans of different particle sizes. 2. Fatty acid utilization by lactating cows. J. Dairy Sci. 77:166-180.

Ushida, K., B. Lassalas, and J. P. Jouany. 1985. Determination of assay parameters for RNA analysis in bacterial and duodenal sample by spectrophotometry. Influence of sample treatment and preservation. Reprod. Nutr. Dev. 25:1037-1046.

Williams, C. H., D. J. David, and O. Iismaa. 1962. The determination of chromic oxide in feces samples by atomic absorption spectrophotometry. J. Agric. Sci. 59:381-385.

Zinn, R. A., and F. N. Owens. 1986. A rapid procedure for purine measurement and its use for estimating net ruminal protein synthesis. Can. J. Anim. Sci. 66:157-166. 